\title{
Soil organic matter dynamics in a North America tallgrass prairie after 9 yr of experimental warming
}

\author{
X. Cheng ${ }^{1,2}$, Y. Luo ${ }^{2}$, X. Xü ${ }^{2}$, R. Sherry ${ }^{2}$, and Q. Zhang ${ }^{1}$ \\ ${ }^{1}$ Key Laboratory of Aquatic Botany and Watershed Ecology, Wuhan Botanical Garden, The Chinese Academy of Sciences, \\ Wuhan 430074, China \\ ${ }^{2}$ Department of Botany and Microbiology, University of Oklahoma, 770 Van Vleet Oval, Norman, OK 73019, USA
}

Received: 1 October 2010 - Published in Biogeosciences Discuss.: 15 November 2010

Revised: 24 April 2011 - Accepted: 5 May 2011 - Published: 9 June 2011

\begin{abstract}
The influence of global warming on soil organic matter (SOM) dynamics in terrestrial ecosystems remains unclear. In this study, we combined soil fractionation with isotope analyses to examine SOM dynamics after nine years of experimental warming in a North America tallgrass prairie. Soil samples from the control plots and the warmed plots were separated into four aggregate sizes $(>2000 \mu \mathrm{m}$, $250-2000 \mu \mathrm{m}, 53-250 \mu \mathrm{m}$, and $<53 \mu \mathrm{m}$ ), and three density fractions (free light fraction - LF, intra-aggregate particulate organic matter - iPOM, and mineral-associated organic matter - mSOM). All fractions were analyzed for their carbon (C) and nitrogen (N) content, and $\delta^{13} \mathrm{C}$ and $\delta^{15} \mathrm{~N}$ values. Warming did not significantly effect soil aggregate distribution and stability but increased $\mathrm{C}_{4}$-derived $\mathrm{C}$ input into all fractions with the greatest in LF. Warming also stimulated decay rates of $\mathrm{C}$ in whole soil and all aggregate sizes. $\mathrm{C}$ in LF turned over faster than that in iPOM in the warmed soils. The $\delta^{15} \mathrm{~N}$ values of soil fractions were more enriched in the warmed soils than those in the control, indicating that warming accelerated loss of soil $\mathrm{N}$. The $\delta^{15} \mathrm{~N}$ values changed from low to high, while $\mathrm{C}: \mathrm{N}$ ratios changed from high to low in the order LF, iPOM, and mSOM due to increased degree of decomposition and mineral association. Overall, warming increased the input of $\mathrm{C}_{4}$-derived $\mathrm{C}$ by $11.6 \%$, which was offset by the accelerated loss of soil C. Our results suggest that global warming simultaneously stimulates $\mathrm{C}$ input via shift in species composition and decomposition of SOM, resulting in negligible net change in soil C.
\end{abstract}

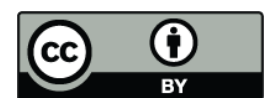

Correspondence to: $\mathrm{X}$. Cheng (xlcheng@fudan.edu.cn)

\section{Introduction}

Recent Intergovernmental Panel on Climate Change report (IPCC, 2007) predicts global average temperature to increase by $1.1-6.4^{\circ} \mathrm{C}$ during current century. Global warming is expected to profoundly impact ecosystem processes such as soil organic matter (SOM) dynamics (e.g., Davidson and Janssens, 2006; Von Fischer et al., 2008). Carbon (C) in SOM accounts for $80 \%$ of terrestrial $\mathrm{C}$ pool and is regarded as an important potential C sink that may help offset the greenhouse effect (e.g., Lal, 2008; Maia et al., 2010). Small changes in SOM stock under global change can potentially effect atmospheric $\mathrm{CO}_{2}$ concentrations (e.g., Batjes and Sombroek, 1997; Marin-Spiotta et al., 2009). In addition, warming-induced changes in SOM regulate the availability of nitrogen $(\mathrm{N})$ for plant growth and ultimately influence the net primary productivity of terrestrial ecosystems. Hence, it is imperative to understand how global warming will effect SOM dynamics.

Effects of warming on SOM dynamics remain a widely debated topic (e.g., Pendall et al., 2004). For example, climatic warming increases soil temperature and hence accelerates organic matter decomposition rates, leading to loss of soil $\mathrm{C}$ and N (e.g., Rustad et al., 2001; Fontaine et al., 2004). Conversely, some studies have reported that warming leads to increases in soil $\mathrm{C}$ and $\mathrm{N}$ because of great increases in biomass and litter inputs in tundra ecosystems (e.g., Welker et al., 2004; Day et al., 2008). These differences are not surprising given response of soils to warming depends on many factors, such as soil moisture and temperature and, in particular, on plant species that provide carbon inputs to soils (e.g., Shaw and Harte, 2001; Fissore et al., 2008). Most SOM derives exclusively from the plant material growing on site. Changes

Published by Copernicus Publications on behalf of the European Geosciences Union. 
in vegetation type are thus expected to alter the quality and quantity of SOM (Cheng et al., 2006; Fissore et al., 2008). Recent climatic warming has already led to dramatic shifts in plant functional groups (e.g., $\mathrm{C}_{3}$ litter with high quality and $\mathrm{C}_{4}$ litter with low quality), and this can effect the accumulation and decomposition patterns of SOM by altering the quantity and quality of plant material entering into soil (Day et al., 2008; Fissore et al., 2008). Therefore, understanding the response of SOM to climatic warming is critical for accurate predictions of long-term ecosystem $\mathrm{C}$ and $\mathrm{N}$ cycling in future climatic scenarios.

However, detecting changes in the SOM stock of terrestrial ecosystem under global change can be difficult, because SOM consists of a complex composition with different physical and chemical stabilities (Van Groenigen et al., 2002; Del Galdo et al., 2003; Marin-Spiotta et al., 2009). To characterize changes in soil C and SOM dynamics correctly, size and density fractionation techniques have been developed to separate bulk soil into fractions that differ in microbial degradability and turnover time (e.g., Jastrow, 1996; Six et al., 2000; Marin-Spiotta et al., 2009). Aggregate size fractionations have shown that $\mathrm{C}$ in SOM associated with larger aggregates has higher turnover rates than $\mathrm{C}$ in SOM associated with smaller aggregates (Jastrow, 1996; Six et al., 2000). Density fractionations result in a light fraction, which is composed of physically unprotected plant debris and it is generally thought to have a rapid turnover as well as a heavy mineral associated fraction, which remains more recalcitrant with a long-term turnover (Balesdent, 1996).

Natural abundance of stable $\mathrm{C}$ isotopes coupled with SOM fractionation technique offers an approach to better quantify SOM dynamics when global change induces a shift in the dominant plant species composition between $\mathrm{C}_{4}$ and $\mathrm{C}_{3}$ (López-Ulloa et al., 2005; John et al., 2005; Auerswald et al., 2009; Marin-Spiotta et al., 2009). Theoretically, differences in the natural stable $\mathrm{C}$ isotope signature between $\mathrm{C}_{3}$ (average $\delta^{13} \mathrm{C}$ value of $-27 \%$ ) and $\mathrm{C}_{4}$ (average $\delta^{13} \mathrm{C}$ value of $-11 \%$ ) plants result in SOM with distinct isotopic signatures. Changes in $\delta^{13} \mathrm{C}$ values of SOM over time following a change in vegetation can be used to examine the relative contribution of $\mathrm{C}_{3}$ - or $\mathrm{C}_{4}$-derived $\mathrm{C}$ to $\mathrm{SOM}$ formation (Del Galdo et al., 2003; Cheng et al., 2006) and quantify SOM decomposition rates (e.g., Liao et al., 2006). Furthermore, soil $\delta^{15} \mathrm{~N}$ values reflect the net effect of $\mathrm{N}$-cycling processes as influenced by climate change and species composition (Robinson, 2001; Dawson et al., 2002; Bijoor et al., 2008). For instance, increased soil temperature has been suggested to enhance rates of $\mathrm{N}$ cycling and loss of $\mathrm{N}$, resulting in ${ }^{15} \mathrm{~N}$ enrichment (Bijoor et al., 2008). The soil $\delta^{15} \mathrm{~N}$ values can be also used to estimate the degree of SOM decomposition and humification (Kramer et al., 2003; Liao et al., 2006; Templer et al., 2007; Marin-Spiotta et al., 2009)

In Central Oklahoma USA Great Plains, a long-term, ongoing experimental warming and clipping experiment was initiated on 21 November 1999 in a tallgrass prairie (Luo et al., 2001), dominated by a mixture of $\mathrm{C}_{4}$ grasses and a few $\mathrm{C}_{3}$ forbs. Warming has resulted in a shift towards a more $\mathrm{C}_{4}$-grass dominated plant community and an increase in aboveground biomass as well as aboveground net primary productivity (ANPP) (Wan et al., 2005; Luo et al., 2009), and hence increased litter input and altered litter quality (An et al., 2005; Cheng et al., 2010). These changes provide a unique opportunity to utilize the natural abundance of $\delta^{13} \mathrm{C}$ and $\delta^{15} \mathrm{~N}$ to evaluate changes in SOM dynamics after nine years of experimental warming. We hypothesized that nine years of warming would significantly increase SOM storage due to warming-induced increases in litter input and changes in litter quality (An et al., 2005; Cheng et al., 2010). To test this hypothesis, we measured the $\delta^{13} \mathrm{C}, \delta^{15} \mathrm{~N}, \mathrm{C}$, and $\mathrm{N}$ concentrations in all SOM aggregates and density fractions in the tallgrass prairie experiment. The specific objectives of this study were to: (1) evaluate the impact of the long-term experimental warming on the $\mathrm{C}$ and $\mathrm{N}$ pools in SOM fractions; (2) quantify amounts of $\mathrm{C}$ derived from $\mathrm{C}_{4}$ vs. $\mathrm{C}_{3}$ sources in SOM fractions after nine years of experimental warming; and (3) estimate the turnover rate of C in SOM fractions in warmed soils.

\section{Materials and methods}

\subsection{Site description}

The experiment was located on Kessler's Farm Field Lab (formerly Great Plain Apiaries, 34 $58^{\prime} 54^{\prime \prime} \mathrm{N}, 97^{\circ} 31^{\prime} 14^{\prime \prime} \mathrm{W}$ ), $40 \mathrm{~km}$ from the Norman campus of the University of Oklahoma, USA. Detailed description of the site characteristics and design of the experiment have been reported elsewhere (See Luo et al., 2001). Briefly, the site is a tallgrass prairie primarily dominated by $\mathrm{C}_{4}$ grasses (Schizachyrium scoparium and Sorghastrum nutans) and $\mathrm{C}_{3}$ forbs (Solidago rigida and Solidago nemoralis). S. scoparium comprises over $40 \%$ of the plantcover, and S. nutans over $20 \%$ (Sherry and Luo, unpublished data). Mean annual temperature is $16.0^{\circ} \mathrm{C}$ with a monthly mean temperature of $3.1^{\circ} \mathrm{C}$ in January and $28.0^{\circ} \mathrm{C}$ in July. Mean annual precipitation is $911.4 \mathrm{~mm}$ (Oklahoma Meteorological Survey). The soil is a silt loam with $36 \%$ sand, $55 \%$ silt, and $10 \%$ clay in the top $15 \mathrm{~cm}$. The proportion of clay increases with depth. The soil is part of the Nash-Lucien complex, which is characterized by a low permeability, high available water capacity, and deep, moderately penetrable root zone (USDA Soil Conservation Service and Oklahoma Agricultural Experiment Station, 1963).

\subsection{Experimental design}

This experiment used a paired factorial design with warming as the main factor nested by a clipping factor. Pairs of $2 \times 2 \mathrm{~m}$ control and warmed plots were replicated six times. One plot has been subjected to continuous $2{ }^{\circ} \mathrm{C}$ warming 
Table 1. The physical soil fraction obtained from a trallgrass prairie after nine years of warming and clipping. Soil fractions analyzed for C, $\mathrm{N}$ concentrations, $\delta^{13} \mathrm{C}$, and $\delta^{15} \mathrm{~N}$ are denoted by bold numbers.

\begin{tabular}{lll}
\hline Aggregates & Density fractionation $\left(1.85 \mathrm{~g} \mathrm{~cm}^{-3}\right)$ & Sieving of broken-down aggregates \\
\hline (1) Macroaggregates $(>2000 \mu \mathrm{m})$ & $\mathbf{( 1 . 1 )}$ free $\mathrm{LF}$ & \\
& $\mathbf{( 1 . 2 )}$ heavy fraction & $\mathbf{( 1 . 2 . 1 )} \mathrm{mSOM}(<53 \mu \mathrm{m})$ \\
& & $\mathbf{( 1 . 2 . 2 )} \mathrm{iPOM}(>53 \mu \mathrm{m})$
\end{tabular}

(2) Macroaggregates $(250-2000 \mu \mathrm{m}) \quad$ (2.1) free LF

(2.2) heavy fraction $\quad$ (2.2.1) $\operatorname{mSOM}(<53 \mu \mathrm{m})$

(2.2.2) $\operatorname{iPOM}(>53 \mu \mathrm{m})$

(3) Microaggregates $(53-250 \mu \mathrm{m})$

(3.1) free LF

(3.2) heavy fraction $\quad$ (3.2.1) $\mathrm{mSOM}(<53 \mu \mathrm{m})$

(3.2.2) $\operatorname{POOM}(>53 \mu \mathrm{m})$

(4) Microaggregates $(<53 \mu \mathrm{m})$

$\mathrm{LF}=$ Light fraction; $\mathrm{POM}=$ Particle organic matter; $\mathrm{POM}=$ intra-aggregate $\mathrm{POM} ; \mathrm{mSOM}=$ mineral associated SOM.

since 12 November 1999, while the control has had ambient temperature. One $165 \times 15 \mathrm{~cm}$ radiant infrared heater (Kalglo Electronics Inc., Bethlehem, PA, USA) with an

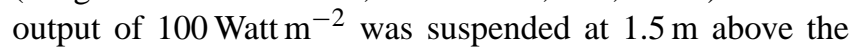
ground in each warmed plot as the heating device. Reflector surface of the heaters were adjusted so as to generate evenly distributed radiant input to soil surface (Kimball, 2005). As a result, temperature increments generated by the infrared heaters were relatively even over the entire area of plots and similar at different soil depths (Wan et al., 2005). A "dummy heater" with the same shape and size as the infrared heater was suspended at the same height in the control plots to simulate the shading effect of the heater on the plant canopy. For each paired plot, the distance between warmed and control plots was approximately $5 \mathrm{~m}$ to avoid heating of the control plots. The distance between the paired plots varied from 20 to $60 \mathrm{~m}$.

Each $2 \times 2 \mathrm{~m}$ plot was divided into four $1 \times 1 \mathrm{~m}$ subplots. Plants in the two diagonal subplots were clipped at the height of $10 \mathrm{~cm}$ above the ground yearly to remove biomass, usually in August. Clipping in this manner effectively mimics agricultural hay mowing, a widely practiced land use in the southern Great Plains. Usually farmers and ranchers in the southern Great Plains mow pasture once or twice per year, depending on rainfall. Clipping also simulates biomass harvest for biofuel feedstock production, although the study was not originally designed to study bioenergy production. The other two diagonal subplots were left unclipped. The four treatments in the experiment were unclipped control (UC), clipped control (CC), unclipped warming (UW), and clipped warming $(\mathrm{CW})$.

\subsection{Litter and soil collection, and soil fractionation}

Litter on the soil surface was collected in clipped plots in August 2008. As the unclipped subplots were designed to have minimal disturbances over the long term, no plant material was taken from the unclipped plots. Collected litter was separated into $\mathrm{C}_{3}$ and $\mathrm{C}_{4}$ species according to morphological traits. Litter from $\mathrm{C}_{3}$ and $\mathrm{C}_{4}$ species, and mixed litter (i.e., mixed $\mathrm{C}_{3}$ and $\mathrm{C}_{4}$ litter) from warmed plots were selected for analyses of $\mathrm{N}$ and $\mathrm{C}$ concentration, and stable $\mathrm{C}$ and $\mathrm{N}$ isotopes $\left(\delta^{13} \mathrm{C}\right.$, and $\left.\delta^{15} \mathrm{~N}\right)$.

Soil samples were collected at a depth of $0-20 \mathrm{~cm}$ with a $4 \mathrm{~cm}$ diameter soil corer in the fall of 2008, nine years after the warming began. Soil samples were air-dried, after which large roots and stone were removed by hand. The method for aggregate separation and size density fractionations of free fraction (LF), intra aggregate particulate organic matter (iPOM), and mineral-associated organic matter (mSOM) was adapted from Six et al. (1998). The fractionation sequences are summarized in Table 1. Four aggregate sizes were separated using wet sieving through a series of sieves (2000, 250, and $53 \mu \mathrm{m})$. A $100 \mathrm{~g}$ air dried sample was submerged for $5 \mathrm{~min}$ in room temperature de-ionized water, on top of the $2000 \mu \mathrm{m}$ sieve. Aggregate separation was achieved by manually moving the sieve up and down $3 \mathrm{~cm}$ with 50 repetitions during a period of $2 \mathrm{~min}$. After the 2 -min cycle, the stable $>2000 \mu \mathrm{m}$ aggregates were gently back-washed off the sieve into an aluminum pan. Floating organic material $(>2000 \mu \mathrm{m})$ was discarded, as this is by definition not considered SOM (Six et al., 1998). Water and soil that passed through the sieve were poured into the next two sieves (one at a time) and the sieving was repeated in a similar fashion, but floating material was retained. Thus, four size fractions were obtained 
( $>2000 \mu \mathrm{m}, 250-2000 \mu \mathrm{m}, 53-250 \mu \mathrm{m}$ and $<53 \mu \mathrm{m}$ ). The aggregates were oven dried at $\left(50^{\circ} \mathrm{C}\right)$, weighed, and stored in glass jars at room temperature.

The density fractionation was carried out by using a solution of $1.85 \mathrm{~g} \mathrm{~cm}^{-3}$ sodium polytungstate (SPT), following the method described in Six et al. (1998). A subsample $(5 \mathrm{~g})$ of each oven-dried $\left(110^{\circ} \mathrm{C}\right)$ aggregate size fraction was suspended in $35 \mathrm{ml}$ of SPT and slowly shaken by hand. The material remaining on the cap and sides of the centrifuge tube was washed into suspension with $10 \mathrm{ml}$ of SPT. After $20 \mathrm{~min}$ of vacuum $(138 \mathrm{kPa})$, the samples were centrifuged $(1250 \mathrm{~g})$ at $20^{\circ} \mathrm{C}$ for $60 \mathrm{~min}$. The floating material (light fraction-LF) was aspirated onto a $20 \mu \mathrm{m}$ nylon filter, subjected to multiple washings with deionized water to remove SPT, and dried at $50^{\circ} \mathrm{C}$. The heavy fraction (HF) was rinsed twice with $50 \mathrm{ml}$ of deionized water and dispersed in $0.5 \%$ sodium hexametaphosphate by shaking for $18 \mathrm{~h}$ on a reciprocal shaker. The dispersed heavy fraction was then passed through a $53 \mu \mathrm{m}$ sieve and the material remaining on the sieve, i.e. the intra-aggregate particulate organic matter (iPOM), was dried $\left(50^{\circ} \mathrm{C}\right)$ and weighed.

\subsection{Carbon, nitrogen, and isotope analyses}

Samples of litter and soil were dried at $50^{\circ} \mathrm{C}$ to constant weight and then ground to pass through 20 -mesh $(0.84 \mathrm{~mm})$ sieves (Cheng et al., 2006). The $\mathrm{C}$ and $\mathrm{N}$ concentrations and $\delta^{13} \mathrm{C}$ and $\delta^{15} \mathrm{~N}$ were measured for all soil fractions and litter materials. Subsamples from all fractions were treated with $1 \mathrm{~N} \mathrm{HCL}$ for $24 \mathrm{~h}$ at room temperature to remove any soil carbonates (Cheng et al., 2006). The $\mathrm{C}$ and $\mathrm{N}$ concentration and $\delta^{13} \mathrm{C}$ and $\delta^{15} \mathrm{~N}$ of soil and litter were determined at University of Arkansas Stable Isotope Laboratory on a Finnigan Delta $^{+}$mass spectrometer (Finnigan MAT, Germany) coupled to a Carlo Erba elemental analyzer (NA1500 CHN Combustion Analyzer, Carlo Erba Strumentazione, Milan, Italy) via a Finnigan Conflo II Interface. Carbon and nitrogen contents of SOM fractions were calculated on an areal basis, correcting for soil depth and density.

The carbon and nitrogen isotope ratio of the soil fractions was expressed as:

$\delta^{\mathrm{h}} X=\left[\left(\frac{X^{\mathrm{h}}}{X^{\mathrm{l}}}\right)_{\text {sample }} /\left(\frac{X^{\mathrm{h}}}{X^{\mathrm{l}}}\right)_{\text {standard }}-1\right] \cdot 1000$

where $X$ is either carbon or nitrogen, " $\mathrm{h}$ " is the heavier isotope, "l" is the lighter isotope. Both $\mathrm{CO}_{2}$ and $\mathrm{N}_{2}$ samples were analyzed relative to internal, working gas standards. Carbon isotope ratios $\left({ }^{13} \mathrm{C}\right)$ are expressed relative to Pee Dee Belemnite $\left(\delta^{13} \mathrm{C}=0.0 \%\right)$; nitrogen stable isotope ratios $\left({ }^{15} \mathrm{~N}\right)$ are expressed relative to air $\left(\delta^{15} \mathrm{~N}=0.0 \%\right)$. Standards (acetanilide and spinach) were analyzed after every ten samples; analytical precision of the instrument was \pm 0.13 for $\delta^{13} \mathrm{C}$ and \pm 0.21 for $\delta^{15} \mathrm{~N}$.
Differences in $\delta^{13} \mathrm{C}$ isotope composition due to photosynthetic pathways allow for the proportion of soil $\mathrm{C}$ derived form $\mathrm{C}_{3}$ or $\mathrm{C}_{4}$ sources to be calculated using a twocompartment mixing-model (Del Galdo et al., 2003; Cheng et al., 2006):

$f_{A}=\frac{\delta_{X}-\delta_{B}}{\delta_{A}-\delta_{B}} \cdot 100 \%$

where $\delta_{X}$ is the $\delta^{13} \mathrm{C}$ of a given fraction isolated from the warmed or control plots, $\delta_{A}$ and $\delta_{B}$ are the isotope values of $\mathrm{C}_{3}$ and $\mathrm{C}_{4}$ plants from these plots, $f_{A}$ is the fraction of $\mathrm{C}_{3}$ vegetation, and $f_{B}\left(1-f_{A}\right)$ is the proportion derived from $\mathrm{C}_{4}$ grasses.

The fraction of new $\mathrm{C}, f_{\text {new }}$, derived from the current vegetation in the warmed soils after nine years of warming is calculated by using the isotope mass balance method (MarinSpiotta et al., 2009):

$f_{\text {new }}=\frac{\delta_{2}-\delta_{0}}{\delta_{1}-\delta_{0}} \cdot 100 \%$

where $\delta_{2}$ and $\delta_{0}$ are $\delta^{13} \mathrm{C}$ values for SOM pools in the warmed and control plots and $\delta_{1}$ is the average $\delta^{13} \mathrm{C}$ value of mixed litter to the SOM pool in the warmed plots, on the assumption that in the past $9 \mathrm{yr}$, no shift in ratio between $\mathrm{C}_{3} / \mathrm{C}_{4}$ input in the control soil occurred.

In Eqs. (2) and (3), because $\delta_{A}$ (or $\left.\delta_{1}\right), \delta_{X}$ (or $\delta_{2}$ ), and $\delta_{B}$ (or $\delta_{0}$ ) are independently measured, the standard errors (SE) of $f$ associated with the use of the mass-balance approach can be calculated using partial derivatives (Phillips and Gregg, 2001) as:

$\sigma_{f}^{2}=\left(\frac{\delta f}{\partial \delta_{A}}\right)^{2} \sigma_{\delta_{A}}^{2}+\left(\frac{\delta f}{\partial \delta_{X}}\right)^{2} \sigma_{\sigma_{X}}^{2}+\left(\frac{\delta f}{\partial \delta_{B}}\right)^{2} \sigma_{\delta_{B}}^{2}$

This can be reduced to:

$\sigma_{f}^{2}=\frac{1}{\left(\delta_{X}-\delta_{B}\right)^{2}}\left[\sigma_{\delta_{A}}^{2}+f^{2} \sigma_{\delta_{X}}^{2}+(1-f) \sigma_{\delta_{B}}^{2}\right]$

where $\sigma_{\delta_{A}}^{2}, \sigma_{\delta_{X}}^{2}$, and $\sigma_{\delta_{B}}^{2}$ represent variances of the mean $\delta_{A}$ (or $\left.\delta_{1}\right), \delta_{X}$ (or $\delta_{2}$ ), and $\delta_{B}$ (or $\delta_{0}$ ), respectively. The $\sigma_{f}$ is the SE of the proportion $(f)$ estimate (Phillips and Gregg, 2001).

Furthermore, decomposition rate constants $(k)$ for old C (i.e. the $\mathrm{C}$ of the organic matter previous to warming) of different fraction of SOM in the warmed plots were calculated using the following equation (Del Galdo et al., 2003):

$\ln \left(f_{\text {old }}\right)=-k t$

where $f_{\text {old }}=\left(1-f_{\text {new }}\right)$ is the proportion of old $\mathrm{C}, k$ is the net relative decomposition rate constant of old $\mathrm{C}$, and $t$ is the age of warming. 


\subsection{Statistics}

Analysis of variance (ANOVA) of paired split-plot design (one pair of plots being considered a block) was conducted to examine the effects of warming on the soil organic $\mathrm{C}$ and $\mathrm{N}$ contents, the $\delta^{13} \mathrm{C}$ and $\delta^{15} \mathrm{~N}$ values, C:N ratios in all soil fractions, and the weight distribution. The differences in soil organic $\mathrm{C}$ and $\mathrm{N}$ contents, the $\delta^{13} \mathrm{C}$ and $\delta^{15} \mathrm{~N}$ values, and $\mathrm{C}: \mathrm{N}$ ratios between aggregate sizes and density fractions were analyzed using one-way ANOVA. All statistical analyses were performed using Stat Soft's Statistica, statistical software for Windows (Version 6.0, StatSoft, Inc., 2001).

\section{Results}

\subsection{The $\delta^{13} \mathrm{C}$ and $\delta^{15} \mathrm{~N}$ values of plant litter}

The $\delta^{13} \mathrm{C}$ values of $\mathrm{C}_{4}$ litter had a mean vale of $-12.74 \%$, while $\mathrm{C}_{3}$ litter had a mean value of $-27.62 \%$ o. Warming significantly increased the $\delta^{13} \mathrm{C}$ values of mixed litter on average by $11.3 \%$ (Table 2 ). Warming significantly enhanced the $\delta^{15} \mathrm{~N}$ values on average by $12.2 \%$ for $\mathrm{C}_{4}$ litter and by $26.1 \%$ for $\mathrm{C}_{3}$ litter, whereas warming slightly increased the $\delta^{15} \mathrm{~N}$ values on average by $8.4 \%$ for mixed litter (Table 2 ).

\subsection{Whole soil $\mathrm{C}$ and $\mathrm{N}$ dynamics}

Whole soil (i.e., total soil) organic $\mathrm{C}$ and $\mathrm{N}$ contents ranged from 2371 to $2707 \mathrm{~g} \mathrm{C} \mathrm{m}^{-2}$, and 284 to $312 \mathrm{~g} \mathrm{~N} \mathrm{~m}^{-2}$, respectively, across all treatments. No significant differences in $\mathrm{C}$ and $\mathrm{N}$ content, or $\mathrm{C}: \mathrm{N}$ ratios among treatments were found (Table 3). Nine-year warming significantly increased the $\delta^{13} \mathrm{C}$ signature of SOM for both clipped and unclipped plots. On average, the warmed plot soils were $1.3 \%$ more enriched in ${ }^{13} \mathrm{C}$ than the control plots. Based on these data, warming increased the fraction of $\mathrm{C}_{4}$-derived $\mathrm{C}$ on average by $11.6 \%$ (Table 4 ). Warming increased the $\delta^{15} \mathrm{~N}$ values of SOM in clipped plots (Table 4).

\subsection{Size distribution, $\mathrm{C}$ and $\mathrm{N}$ contents, and $\delta^{13} \mathrm{C}$ and $\delta^{15} \mathrm{~N}$ of soil aggregates}

Aggregate distribution was not significantly effected by warming or clipping (Fig. 1). Warming significantly decreased soil organic $\mathrm{C}$ and $\mathrm{N}$ content in microaggregates $(<250 \mu \mathrm{m})$ in clipped plots but not in other aggregate size classes (Table 4). No significant differences in C:N ratios were found across aggregate size and treatments (Fig. 2). Generally, macroaggregates $(>250 \mu \mathrm{m})$ contained significantly more $\mathrm{C}$ and $\mathrm{N}$ (78-84\%) than microaggregates in all treatments (Table 4).

Warming resulted in no significant increase in the $\delta^{13} \mathrm{C}$ values of all aggregate sizes compared to the control plots (Table 5), indicating that warming possibly stimulated input of $\mathrm{C}_{4}$-derived C (Fig. 3a). Warming-induced increases in the
Table 2. The values of $\delta^{13} \mathrm{C}$ and $\delta^{15} \mathrm{~N}$ of litter of $\mathrm{C}_{3}, \mathrm{C}_{4}$ species and mixed litter under the warming treatment. Data are expressed as mean $\pm \mathrm{SE}, n=6$. Different letters indicate statistical significance at $P<0.05$ between the two treatments.

\begin{tabular}{llll}
\hline Variable & Species & Control & Warming \\
\hline$\delta^{13} \mathrm{C}(\% \circ)$ & $\mathrm{C}_{4}$ & $-12.48 \pm 0.24^{\mathrm{a}}$ & $-13.01 \pm 0.25^{\mathrm{a}}$ \\
& $\mathrm{C}_{3}$ & $-27.54 \pm 0.15^{\mathrm{a}}$ & $-27.69 \pm 0.13^{\mathrm{a}}$ \\
& Mixed litter & $-16.19 \pm 0.30^{\mathrm{a}}$ & $-14.54 \pm 0.21^{\mathrm{b}}$ \\
\hline$\delta^{15} \mathrm{~N}(\% \circ)$ & $\mathrm{C}_{4}$ & $-4.51 \pm 0.12^{\mathrm{a}}$ & $-4.02+0.19^{\mathrm{b}}$ \\
& $\mathrm{C}_{3}$ & $-5.84 \pm 0.15^{\mathrm{a}}$ & $-4.63 \pm 0.17^{\mathrm{b}}$ \\
& Mixed litter & $-5.81 \pm 0.24^{\mathrm{a}}$ & $-5.36 \pm 0.30^{\mathrm{a}}$ \\
\hline
\end{tabular}

fraction of $\mathrm{C}_{4}$-derived $\mathrm{C}$ ranged from $5.3 \%$ to $10.8 \%$ among aggregate size classes, with the highest in the $>2000 \mu \mathrm{m}$ macroaggregate class (Fig. 3b).

The $\delta^{15} \mathrm{~N}$ values of each aggregate size were significantly more enriched in the warmed plots than the control (Table 5). There were no significant differences in $\delta^{15} \mathrm{~N}$ values between aggregates $(>53 \mu \mathrm{m})$, but microaggregates $(<53 \mu \mathrm{m})$ had a significantly higher $\delta^{15} \mathrm{~N}$ value than all other aggregate size classes (Table 5).

\subsection{Density fraction: $\mathrm{C}$ and $\mathrm{N}$ contents, and $\delta^{13} \mathrm{C}$ and $\delta^{15} \mathrm{~N}$ in $\mathrm{LF}$, iPOM and $\mathrm{mSOM}$}

LF accounted for the smallest fraction of total SOM, whereas mSOM accounted for the largest (74-79\%) fraction of total SOM in all aggregate size classes across all treatments (Table 4). Warming significantly decreased soil organic $\mathrm{C}$ and $\mathrm{N}$ contents in iPOM in macroaggregates $(>2000 \mu \mathrm{m})$ in clipped plots but not in any other SOM classes. $\mathrm{C}$ and $\mathrm{N}$ content in $\mathrm{mSOM}$ and $\mathrm{iPOM}$ significantly decreased with size class, whereas the highest $\mathrm{C}$ and $\mathrm{N}$ contents in LF were found in 2000-250 $\mu \mathrm{m}$ macroaggregates (Table 4). C:N ratio significantly increased in LF of $250-53 \mu \mathrm{m}$ microaggregates but not in any other SOM classes under warming in comparison to control (Fig. 4). C:N ratios decreased from LF to iPOM to $\mathrm{mSOM}$ in all aggregate classes across treatments (Fig. 4).

Warming resulted in an increase in $\delta^{13} \mathrm{C}$ values across all density fractions in each aggregate size (Table 5). The warming-induced increase was significant for $\delta^{13} \mathrm{C}$ values from LF in $>2000 \mu \mathrm{m}$ macroaggregates in clipped plots. The $\delta^{13} \mathrm{C}$ values were generally more enriched in mSOM than LF and iPOM across aggregate sizes and treatments (Table 5). Warming-induced increase in $\mathrm{C}_{4}$-derived $\mathrm{C}$ was the highest for $\mathrm{LF}$ in $>2000 \mu \mathrm{m}$ macroaggregates among all aggregates and density fractions (Fig. 5b). In general, warming stimulated more $\mathrm{C}_{4}$-derived $\mathrm{C}$ input into $\mathrm{LF}$ than $\mathrm{PPOM}$ and $\mathrm{mSOM}$ across all aggregate sizes, and more into larger than smaller aggregate sizes (Fig. 5b). 
Table 3. Soil organic $\mathrm{C}$ and $\mathrm{N}$ content, ${ }^{13} \mathrm{C}$ - and ${ }^{15} \mathrm{~N}$ signature, fraction of $\mathrm{C}_{4}$-derived $\mathrm{C}\left(f_{B}\right)$, and the $\mathrm{C}: \mathrm{N}$ ratio of whole soils in a tallgrass prairie ( $0-20 \mathrm{~cm}$ depth) after nine years of warming and clipping. Data are expressed as mean $\pm \mathrm{SE}, n=6$. Different letters indicate statistical significance at $P<0.05$ among the four treatments. Abbreviations: UC, unclipped control; CC, clipped control; UW, unclipped warming; CW, clipped warming.

\begin{tabular}{lcccccr}
\hline Treatment & $\mathrm{C}\left(\mathrm{g} \mathrm{C} \mathrm{m}^{-2}\right)$ & $\delta^{13} \mathrm{C}(\% \circ)$ & $f_{B}(\%)$ & $\mathrm{N}\left(\mathrm{g} \mathrm{N} \mathrm{m}^{-2}\right)$ & $\mathrm{C}: \mathrm{N}$ & $\delta^{15} \mathrm{~N}(\% o)$ \\
\hline $\mathrm{UC}$ & $2529 \pm 478^{\mathrm{a}}$ & $-18.48 \pm 3.1^{\mathrm{b}}$ & $60.2 \pm 7.3^{\mathrm{b}}$ & $299 \pm 55^{\mathrm{a}}$ & $8.4 \pm 0.7^{\mathrm{a}}$ & $2.70 \pm 1.0^{\mathrm{a}}$ \\
$\mathrm{UW}$ & $2693 \pm 655^{\mathrm{a}}$ & $-17.26 \pm 3.0^{\mathrm{a}}$ & $71.5 \pm 6.9^{\mathrm{a}}$ & $303 \pm 56^{\mathrm{a}}$ & $8.9 \pm 2^{\mathrm{a}}$ & $2.93 \pm 0.7^{\mathrm{a}}$ \\
$\mathrm{CC}$ & $2371 \pm 352^{\mathrm{a}}$ & $-18.08 \pm 2.8^{\mathrm{b}}$ & $62.8 \pm 5.7^{\mathrm{b}}$ & $312 \pm 41^{\mathrm{a}}$ & $7.6 \pm 0.6^{\mathrm{a}}$ & $2.6 \pm 0.6^{\mathrm{b}}$ \\
$\mathrm{CW}$ & $2707 \pm 536^{\mathrm{a}}$ & $-16.79 \pm 2.6^{\mathrm{a}}$ & $74.7 \pm 8.3^{\mathrm{a}}$ & $284 \pm 48^{\mathrm{a}}$ & $9.5 \pm 1^{\mathrm{a}}$ & $3.53 \pm 0.7^{\mathrm{a}}$ \\
\hline
\end{tabular}

Table 4. Soil organic $\mathrm{C}$ and $\mathrm{N}$ content of soil fractions under four treatments after nine years of warming and clipping. Data are expressed as mean $\pm \mathrm{SE}, n=6$. Different letters indicate statistical significance at $P<0.05$ among the four treatments. See Table 3 for abbreviations.

\begin{tabular}{|c|c|c|c|c|c|c|c|c|}
\hline \multirow[t]{2}{*}{ Fractions } & \multicolumn{4}{|c|}{$\mathrm{C}\left(\mathrm{g} \mathrm{Cm}^{-2}\right)$} & \multicolumn{4}{|c|}{$\mathrm{N}\left(\mathrm{g} \mathrm{N} \mathrm{m}^{-2}\right)$} \\
\hline & UC & UW & $\mathrm{CC}$ & $\mathrm{CW}$ & $\mathrm{UC}$ & UW & $\mathrm{CC}$ & $\mathrm{CW}$ \\
\hline$>2000 \mu \mathrm{m}$ & $1214 \pm 306^{\mathrm{a}}$ & $1399 \pm 268^{a}$ & $1171 \pm 318^{a}$ & $1210 \pm 277^{\mathrm{a}}$ & $145.9 \pm 36.1^{\mathrm{a}}$ & $156.4 \pm 33.2^{\mathrm{a}}$ & $149.7 \pm 32.7^{\mathrm{a}}$ & $117.5 \pm 19.3^{2}$ \\
\hline $\mathrm{LF}$ & $56 \pm 7^{\mathrm{a}}$ & $43 \pm 5^{\mathrm{a}}$ & $31 \pm 4^{\mathrm{b}}$ & $20 \pm 3^{\mathrm{b}}$ & $2.4 \pm 0.4^{\mathrm{a}}$ & $1.6 \pm 0.3^{\mathrm{a}}$ & $2.2 \pm 0.4^{\mathrm{a}}$ & $1.31 \pm 0.3^{\mathrm{a}}$ \\
\hline iPOM & $162 \pm 24^{\mathrm{a}}$ & $142 \pm 23^{\mathrm{a}}$ & $105 \pm 13^{\mathrm{a}}$ & $65 \pm 11^{\mathrm{b}}$ & $11.1 \pm 1.4^{\mathrm{a}}$ & $11.7 \pm 1.4^{\mathrm{a}}$ & $11.6 \pm 2.3^{\mathrm{a}}$ & $6.34 \pm 1.1^{\mathrm{b}}$ \\
\hline $\mathrm{mSOM}$ & $990 \pm 142^{\mathrm{a}}$ & $1213 \pm 290^{\mathrm{a}}$ & $1032 \pm 122^{\mathrm{a}}$ & $1122 \pm 116^{\mathrm{a}}$ & $136.5 \pm 20.2^{\mathrm{a}}$ & $139.6 \pm 23.3^{\mathrm{a}}$ & $137.3 \pm 30.3^{\mathrm{a}}$ & $112.3 \pm 19.2^{\mathrm{a}}$ \\
\hline $2000-250 \mu \mathrm{m}$ & $1022 \pm 273^{a}$ & $979 \pm 265^{\mathrm{a}}$ & $806 \pm 207^{a}$ & $1160 \pm 303^{\mathrm{a}}$ & $104.5 \pm 25.4^{\mathrm{a}}$ & $113.5 \pm 32.3^{\mathrm{a}}$ & $106.7 \pm 14.9^{\mathrm{a}}$ & $120.1 \pm 22.7^{\circ}$ \\
\hline LF & $88 \pm 9.4^{\mathrm{a}}$ & $79 \pm 10^{\mathrm{a}}$ & $85 \pm 9^{\mathrm{a}}$ & $88 \pm 10^{\mathrm{a}}$ & $5.6 \pm 0.7^{\mathrm{a}}$ & $4.6 \pm 0.5^{\mathrm{a}}$ & $4.4 \pm 0.6^{\mathrm{a}}$ & $5.5 \pm 0.8^{\mathrm{a}}$ \\
\hline iPOM & $51 \pm 9^{\mathrm{a}}$ & $73 \pm 12^{\mathrm{a}}$ & $55 \pm 8^{\mathrm{a}}$ & $64 \pm 12^{\mathrm{a}}$ & $5.8 \pm 1.1^{\mathrm{a}}$ & $10.4 \pm 1.5^{\mathrm{a}}$ & $5.0 \pm 0.9^{\mathrm{a}}$ & $5.3 \pm 1.1^{\mathrm{a}}$ \\
\hline $\mathrm{mSOM}$ & $879 \pm 215^{\mathrm{a}}$ & $812 \pm 212^{\mathrm{a}}$ & $663 \pm 103^{a}$ & $1005 \pm 136^{\mathrm{a}}$ & $94.7 \pm 10.2^{\mathrm{a}}$ & $95.3 \pm 11.3^{\mathrm{a}}$ & $98.77 \pm 15.3^{\mathrm{a}}$ & $111.3 \pm 21.2^{2}$ \\
\hline $250-53 \mu \mathrm{m}$ & $266 \pm 57^{b}$ & $286 \pm 73^{b}$ & $344 \pm 77^{\mathrm{a}}$ & $307 \pm 63^{\mathrm{b}}$ & $37.4 \pm 8.3^{\mathrm{b}}$ & $33.8 \pm 10.1^{\mathrm{b}}$ & $44.4 \pm 7.3^{\mathrm{a}}$ & $37.7 \pm 7.2^{\mathrm{b}}$ \\
\hline $\mathrm{LF}$ & $19 \pm 3^{\mathrm{a}}$ & $11 \pm 4^{\mathrm{a}}$ & $20 \pm 3^{\mathrm{a}}$ & $19 \pm 3^{\mathrm{a}}$ & $2.1 \pm 0.3^{\mathrm{a}}$ & $0.7 \pm 0.3^{\mathrm{a}}$ & $1.34 \pm 0.5^{\mathrm{a}}$ & $1.20 \pm 0.4^{\mathrm{a}}$ \\
\hline iPOM & $25 \pm 5^{\mathrm{a}}$ & $31 \pm 6^{\mathrm{a}}$ & $25 \pm 7^{\mathrm{a}}$ & $19 \pm 4^{\mathrm{a}}$ & $2.18 \pm 0.4^{\mathrm{a}}$ & $2.0 \pm 0.6^{\mathrm{a}}$ & $2.0 \pm 0.5^{\mathrm{a}}$ & $1.4 \pm 0.4^{\mathrm{a}}$ \\
\hline mSOM & $218 \pm 32^{\mathrm{a}}$ & $240 \pm 29^{\mathrm{a}}$ & $295 \pm 32^{\mathrm{a}}$ & $262 \pm 33^{\mathrm{a}}$ & $33.7 \pm 5.2^{\mathrm{a}}$ & $31.3 \pm 3.3^{\mathrm{a}}$ & $42.0 \pm 4.2^{\mathrm{b}}$ & $33.8 \pm 3.2^{\mathrm{a}}$ \\
\hline$<53 \mu \mathrm{m}$ & $36.4 \pm 13^{\mathrm{b}}$ & $45.5 \pm 16^{\mathrm{b}}$ & $58.5 \pm 13^{\mathrm{a}}$ & $40.1 \pm 12^{\mathrm{b}}$ & $5.5 \pm 1.2^{\mathrm{b}}$ & $5.8 \pm 0.9^{\mathrm{b}}$ & $7.4 \pm 1.4^{\mathrm{a}}$ & $5.9 \pm 0.8^{b}$ \\
\hline
\end{tabular}

$\mathrm{LF}=$ Light fraction; $\mathrm{POM}=$ Particle organic matter; $\mathrm{iPOM}=$ intra-aggregate $\mathrm{POM} ; \mathrm{mSOM}=$ mineral associated $\mathrm{SOM}$.

In general, warming significantly increased $\delta^{15} \mathrm{~N}$ values of LF, iPOM, and mSOM across aggregate sizes (Table 5). mSOM had the highest $\delta^{15} \mathrm{~N}$ value and LF had the lowest $\delta^{15} \mathrm{~N}$ value among density fractions in all aggregate sizes across treatments (Table 5).

\subsection{Soil C turnover}

Experimental warming stimulated both new $\mathrm{C}$ input from $\mathrm{C}_{4}$ photosynthesis and decay rate of old $\mathrm{C}$ (Table 6). New $\mathrm{C}$ inputs in whole soil were greater than those in all aggregates. New C inputs were greater in LF than in IPOM, with the greatest in $>2000 \mu \mathrm{m}$ macroaggregates. Overall, new $\mathrm{C}$ inputs in soil fractions decreased for smaller aggregates except for mSOM (Table 6). Accordingly, decay rates for old C in whole soil were faster than those for all aggregates. The fastest decay rates were found in LF in $>2000 \mu \mathrm{m}$ macroaggregates, and LF had a greater decay rate than iPOM for all SOM classes (Table 6).

\section{Discussion}

Warming did not significantly increase total soil $\mathrm{C}$ and $\mathrm{N}$ storage, but other aspects of SOM dynamics did change. Warming effects at our study site were previously characterized by increased biomass growth and ANPP, a shift toward greater $\mathrm{C}_{4}$ species dominance, and increased litter input (Wan et al., 2005; Luo et al., 2009; Cheng et al., 2010). Our stable isotope analysis in this present study confirmed that the $\delta^{13} \mathrm{C}$ abundance in SOM in the warmed soils was more enriched than in the control soils (Table 3), resulting from a higher contribution of $\mathrm{C}_{4}$ residuals. Indeed, warminginduced increases in $\mathrm{C}_{4}$ plants and decreases in $\mathrm{C}_{3}$ plants led to increases in the fraction of $\mathrm{C}_{4}$-derived $\mathrm{C}$ on average by $11.6 \%$ (Table 3 ). However, increases in $\mathrm{C}$ inputs and changes in SOM quality after 9-yr warming did not significantly increase total soil organic $\mathrm{C}$ and $\mathrm{N}$ content (Table 3; Niu et al., 2010). 


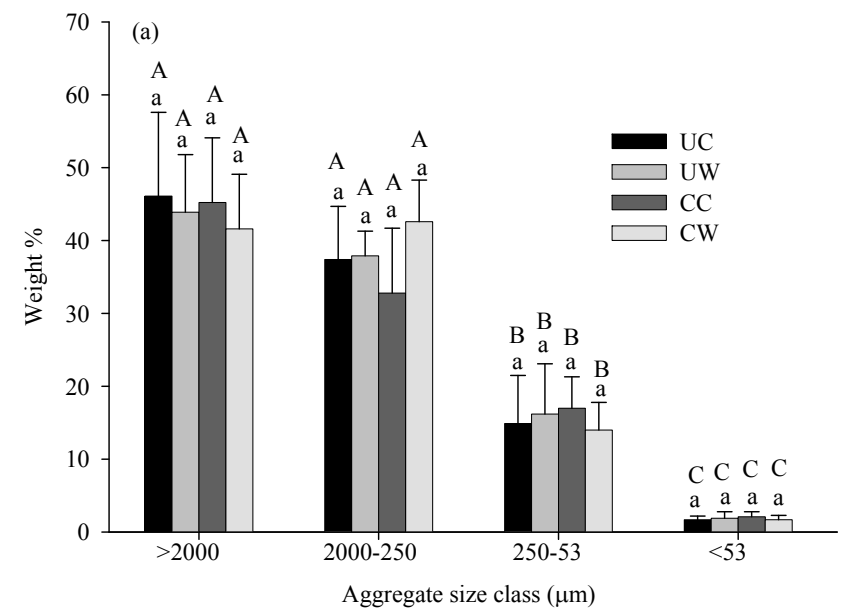

Fig. 1. Weight distribution among aggregate size classes under four treatments after nine years of warming and clipping. Values followed by a different lowercase letter are significantly different within aggregate size classes among treatments. Values followed by a different capital letter are significantly different among aggregate size classes under treatments. Abbreviations: UC, unclipped control; CC, clipped control; UW, unclipped warming; CW, clipped warming.

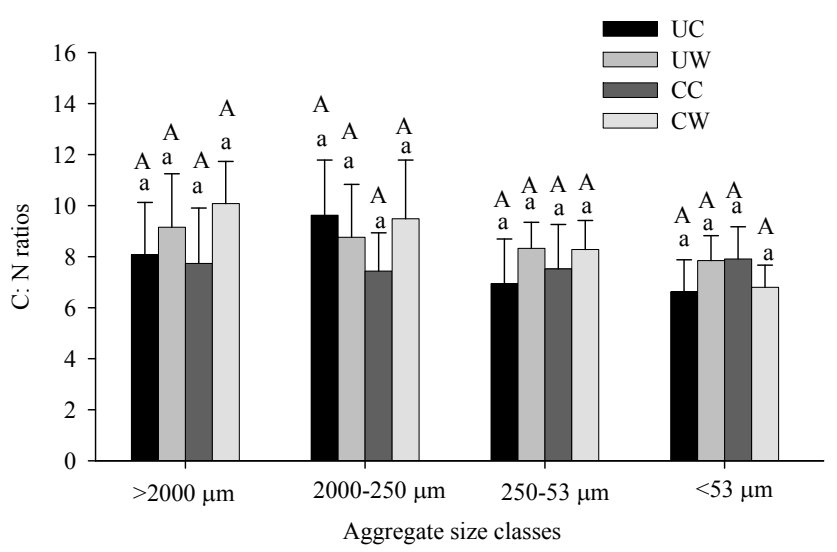

Fig. 2. C:N ratios of aggregate size classes under four treatments after nine years of warming and clipping. See Fig. 1 for the explanation of the symbols.

The main processes that control soil SOM storage under warming are determined by a balance between litter input and soil C respiration (e.g., Shaw and Harte, 2001; Fissore et al., 2008). Our previous study found warming increased soil respiration (Zhou et al., 2007), similar to other warming studies (e.g., Rustad et al., 2001; Fontaine et al., 2004). Furthermore, Wynn and Bird (2007) have found that the active pool of SOM derived from $\mathrm{C}_{4}$ plants decomposes faster than the total pool of SOM. Warming-induced increases in $\mathrm{C}_{4}$-derived $\mathrm{C}$ in SOM pool (Table 3) likely accelerates decay rates of SOM in warmed soils. Thus, unchanged SOM stock in our warming experiment possibly resulted from concur-

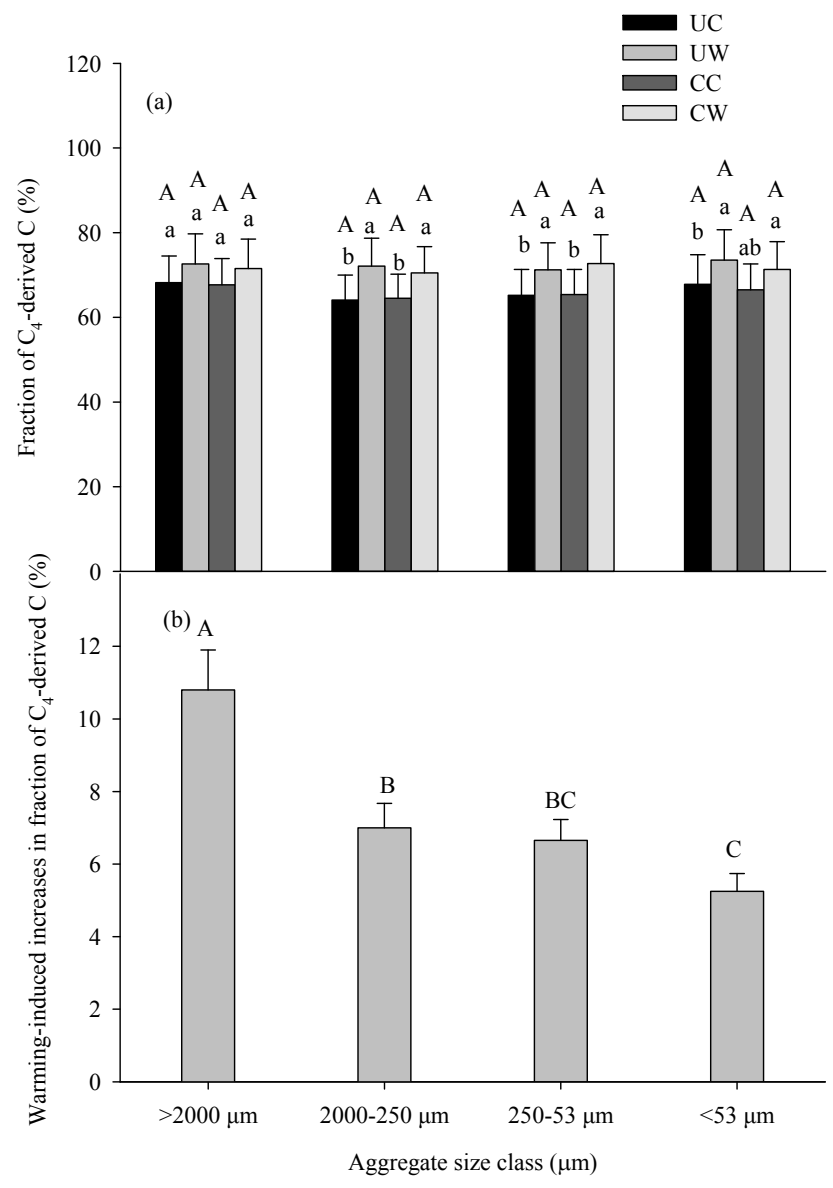

Fig. 3. Fraction of $\mathrm{C}_{4}$-derived $\mathrm{C}$ of aggregate size classes under four treatments after nine years of warming and clipping (a), and warming-induced increases in the fraction of $\mathrm{C}_{4}$-derived $\mathrm{C}$ of aggregate size classes in warmed soils (b). Vales followed by a different lowercase letter are significantly different within aggregate size classes among treatments. Values followed by a different capital are significantly different among aggregate size classes under treatments.

rent increases in litter inputs to soil (Luo et al., 2009; Cheng et al., 2010) and decomposition rates (Zhou et al., 2007).

Similarly, warming did not significantly change soil aggregate size distribution (Fig. 1) and soil organic $\mathrm{C}$ and $\mathrm{N}$ contents (Table 4). Although warming induced a shift from $\mathrm{C}_{3}$ to $\mathrm{C}_{4}$ plant species, which may effect SOM quality and input (Luo et al., 2009; Cheng et al., 2010), warming did not effect the level of soil aggregation (Fig. 1). These results are in agreement with Scott (1998), who reported grass species had no effect on size-distribution of soil aggregates or organic matter concentration. However, the $\mathrm{C}$ and $\mathrm{N}$ content of different size fractions are primarily controlled by the amount of each aggregate size (Elliott, 1986; Van Groenigen et al., 2002). We found that macroaggregates $(>250 \mu \mathrm{m})$ contained significantly more $\mathrm{C}$ and $\mathrm{N}$ than microaggregates (Table 4), indicating that organic $\mathrm{C}$ and $\mathrm{N}$ content generally decrease 
Table 5. $\delta^{13} \mathrm{C}$ and $\delta^{15} \mathrm{~N}$ values of soil fractions under four treatments after nine years of warming and clipping. Data are expressed as mean $\pm \mathrm{SE}, n=6$. Different letters indicate statistical significance at $P<0.05$ among the four treatments. See Table 3 for abbreviations.

\begin{tabular}{|c|c|c|c|c|c|c|c|c|}
\hline Fractions & \multicolumn{4}{|c|}{$\delta^{13} \mathrm{C}(\% \circ)$} & \multicolumn{4}{|c|}{$\delta^{15} \mathrm{~N}(\% \circ)$} \\
\hline$>2000 \mu \mathrm{m}$ & $-18.3 \pm 3.3^{\mathrm{a}}$ & $-17.1 \pm 3.4^{\mathrm{a}}$ & $-18.4 \pm 3.1^{\mathrm{a}}$ & $17.3 \pm 1.8^{\mathrm{a}}$ & $2.51 \pm 0.7^{b}$ & $3.06 \pm 1.1^{\mathrm{a}}$ & $2.82 \pm 0.9^{\mathrm{b}}$ & $3.37 \pm 1.1^{\mathrm{a}}$ \\
\hline iPOM & $-19.5 \pm 2.3^{\mathrm{a}}$ & $-19.1 \pm 3.2^{\mathrm{a}}$ & $-20.1 \pm 2.6^{\mathrm{a}}$ & $-18.2 \pm 2.9^{\mathrm{a}}$ & $1.37 \pm 0.6^{\mathrm{b}}$ & $2.07 \pm 0.8^{\mathrm{a}}$ & $1.46 \pm 0.6^{\mathrm{b}}$ & $2.21 \pm 0.7^{\circ}$ \\
\hline $\mathrm{mSOM}$ & $-17.8 \pm 3.4^{\mathrm{a}}$ & $-17.1 \pm 3.6^{\mathrm{a}}$ & $-17.4 \pm 3.2^{\mathrm{a}}$ & $-17.1 \pm 3.3^{\mathrm{a}}$ & $4.74 \pm 1.1^{\mathrm{a}}$ & $4.94 \pm 1.5^{\mathrm{a}}$ & $4.63 \pm 3.2^{\mathrm{a}}$ & $4.82 \pm 0.8^{\circ}$ \\
\hline $2000-250 \mu \mathrm{m}$ & $-17.9 \pm 4.3^{\mathrm{a}}$ & $-17.2 \pm 2.7^{\mathrm{a}}$ & $-17.8 \pm 2.8^{\mathrm{a}}$ & $-17.4 \pm 2.9^{a}$ & $2.73 \pm 0.7^{b}$ & $3.40 \pm 1.1^{\mathrm{a}}$ & $2.47 \pm 0.9^{b}$ & $3.50 \pm 0.7^{a}$ \\
\hline iPOM & $-18.9 \pm 2.7^{\mathrm{a}}$ & $-18.0 \pm 2.1^{\mathrm{a}}$ & $-19.2 \pm 3.3^{\mathrm{a}}$ & $-18.9 \pm 2.7^{\mathrm{a}}$ & $1.14 \pm 0.9^{b}$ & $1.11 \pm 1.1^{\mathrm{b}}$ & $1.11 \pm 1.0^{\mathrm{b}}$ & $2.61 \pm 0.8^{\circ}$ \\
\hline $\mathrm{mSOM}$ & $-17.9 \pm 3.0^{\mathrm{a}}$ & $-17.0 \pm 3.3^{\mathrm{a}}$ & $-17.8 \pm 3.2^{\mathrm{a}}$ & $-17.2 \pm 3.6^{\mathrm{a}}$ & $4.02 \pm 0.6^{\mathrm{b}}$ & $3.93 \pm 0.7^{\mathrm{b}}$ & $3.92 \pm 0.9^{b}$ & $4.92 \pm 0.8^{\circ}$ \\
\hline $250-53 \mu \mathrm{m}$ & $-17.7 \pm 2.2^{\mathrm{a}}$ & $-17.3 \pm 3.2^{\mathrm{a}}$ & $-17.8 \pm 1.8^{\mathrm{a}}$ & $-17.1 \pm 2.8^{\mathrm{a}}$ & $2.98 \pm 0.8^{b}$ & $3.53 \pm 0.8^{\mathrm{a}}$ & $3.39 \pm 1.1^{\mathrm{a}}$ & $3.81 \pm 0.8^{\circ}$ \\
\hline $\mathrm{LF}$ & $-19.4 \pm 1.3^{\mathrm{a}}$ & $-19.0 \pm 1.4^{\mathrm{a}}$ & $-19.8 \pm 1.6^{\mathrm{a}}$ & $-19.1 \pm 1.0^{\mathrm{a}}$ & $-0.12 \pm 0.4^{\mathrm{a}}$ & $-0.11 \pm 0.2^{\mathrm{a}}$ & $-0.32 \pm 0.8^{\mathrm{a}}$ & $-0.11 \pm 0.7^{\mathrm{a}}$ \\
\hline iPOM & $-19.4 \pm 2.0^{\mathrm{a}}$ & $-19.2 \pm 2.5^{\mathrm{a}}$ & $-19.5 \pm 2.1^{\mathrm{a}}$ & $-19.3 \pm 2.4^{\mathrm{a}}$ & $0.76 \pm 0.9^{\mathrm{b}}$ & $1.03 \pm 1.3^{\mathrm{b}}$ & $1.13 \pm 0.9^{b}$ & $2.86 \pm 1.0^{\circ}$ \\
\hline
\end{tabular}

$\mathrm{LF}=$ Light fraction $; \mathrm{POM}=$ Particle organic matter; $\mathrm{iPOM}=$ intra-aggregate $\mathrm{POM} ; \mathrm{mSOM}=$ mineral associated $\mathrm{SOM}$.

Table 6. New $\mathrm{C}$ input $\left(f_{\text {new }}\right)$, and decay rate $\left(k, \mathrm{yr}^{-1}\right)$ of old $\mathrm{C}$ of soil fractions $(0-20 \mathrm{~cm})$ in warmed soils after nine years of experimental warming.

\begin{tabular}{lcc}
\hline Fraction & $f_{\text {new }},(\%)$ & Decay rate $(k)$ of old C \\
\hline Whole soil & $33.7 \pm 2.6$ & $0.046 \pm 0.003$ \\
\hline$>2000 \mu \mathrm{m}$ & $30.1 \pm 3.4$ & $0.040 \pm 0.003$ \\
LF & $36.3 \pm 4.1$ & $0.144 \pm 0.02$ \\
iPOM & $20.4 \pm 1.7$ & $0.025 \pm 0.003$ \\
mSOM & $16.0 \pm 2.3$ & $0.019 \pm 0.002$ \\
\hline $2000-250 \mu \mathrm{m}$ & $17.3 \pm 19$ & $0.021 \pm 0.002$ \\
LF & $20.0 \pm 2.7$ & $0.025 \pm 0.003$ \\
iPOM & $12.4 \pm 1.5$ & $0.015 \pm 0.001$ \\
mSOM & $22.4 \pm 2.8$ & $0.028 \pm 0.002$ \\
\hline $250-53 \mu \mathrm{m}$ & $16.2 \pm 1.3$ & $0.02 \pm 0.001$ \\
LF & $11.0 \pm 0.9$ & $0.013 \pm 0.001$ \\
iPOM & $4.9 \pm 0.6$ & $0.006 \pm 0.001$ \\
$\mathrm{mSOM}$ & $11.7 \pm 1.3$ & $0.014 \pm 0.001$ \\
\hline$<53 \mu \mathrm{m}$ & $10.7 \pm 0.8$ & $0.012 \pm 0.001$ \\
\hline
\end{tabular}

$\mathrm{LF}=$ Light fraction; $\mathrm{POM}=$ Particle organic matter; $\mathrm{iPOM}=$ intra-aggregate $\mathrm{POM}$; $\mathrm{mSOM}=$ mineral associated SOM.

with decreasing aggregate size (Elliott, 1986; Puget et al., 1995). Additionally, warming increased $\mathrm{C}_{4}$-derived $\mathrm{C}$ in all aggregate size with the highest $\mathrm{C}_{4}$-derived $\mathrm{C}$ in $>2000 \mu \mathrm{m}$ macroaggreates (Fig. $3 \mathrm{~b}$ ), supporting the evidence that new $\mathrm{C}$ is incorporated more rapidly in coarse SOM than in fine SOM fractions (Desjardins et al., 2004; Schwendenmann and Pendall, 2006).
It is well known that LF, iPOM, and mSOM have different chemical compositions and turnover times (Trumbore, 2000; Wynn and Bird, 2007). Higher C:N ratios of LF reflect more recent litter inputs, while mSOM had much lower $\mathrm{C}: \mathrm{N}$ ratios (Fig. 4). Decreasing C:N ratios in soil C fractions have been associated with increasing SOM decomposition and mineral association (John et al., 2005; Marin-Spiotta et al., 2009). Moreover, the ${ }^{15} \mathrm{~N}$ values enriched from $\mathrm{LF}$ to iPOM to $\mathrm{mSOM}$ provided further evidence to support the degree of decomposition and humification of SOM. Similar to other studies (Liao et al., 2006; Marin-Spiotta et al., 2009), the ${ }^{15} \mathrm{~N}$ values of the $<53 \mu \mathrm{m}$ microaggreates were higher than other aggregates (Table 5). In general, low ${ }^{15} \mathrm{~N}$ values are related to recent organic matter inputs (litter, roots), whereas high ${ }^{15} \mathrm{~N}$ values in silts + clays $(<53 \mu \mathrm{m})$ are associated with increasing SOM transformation and humification.

The ${ }^{15} \mathrm{~N}$ values of soil fractions were more enriched in warmed soil than in the control soil (Table 5). It suggests that the natural abundance of ${ }^{15} \mathrm{~N}$ in soil becomes enriched in ${ }^{15} \mathrm{~N}$ in the warmed soil by the process of $\mathrm{N}$ loss from soil through increased mineralization and possibly nitrate leaching compared to control sites (Rustad et al., 2001; Bijoor et al., 2008). Indeed, warming resulted in no significant decreases in total soil $\mathrm{N}$ pools, on average by $10 \%$ in the clipped plots in our study (Table 3). SOM decomposition typically results in an enrichment in $\delta^{15} \mathrm{~N}$ (Liao et al., 2006; Marin-Spiotta et al., 2009), so higher ${ }^{15} \mathrm{~N}$ for the warmed soils relative to the control soils in our study would suggest that the SOM in the warmed soils is more decomposed than the control soils.

Even though there were no significant increases in SOM pools after nine years of warming, isotopic measurements and turnover time estimates suggest different $\mathrm{C}$ decay rates of 


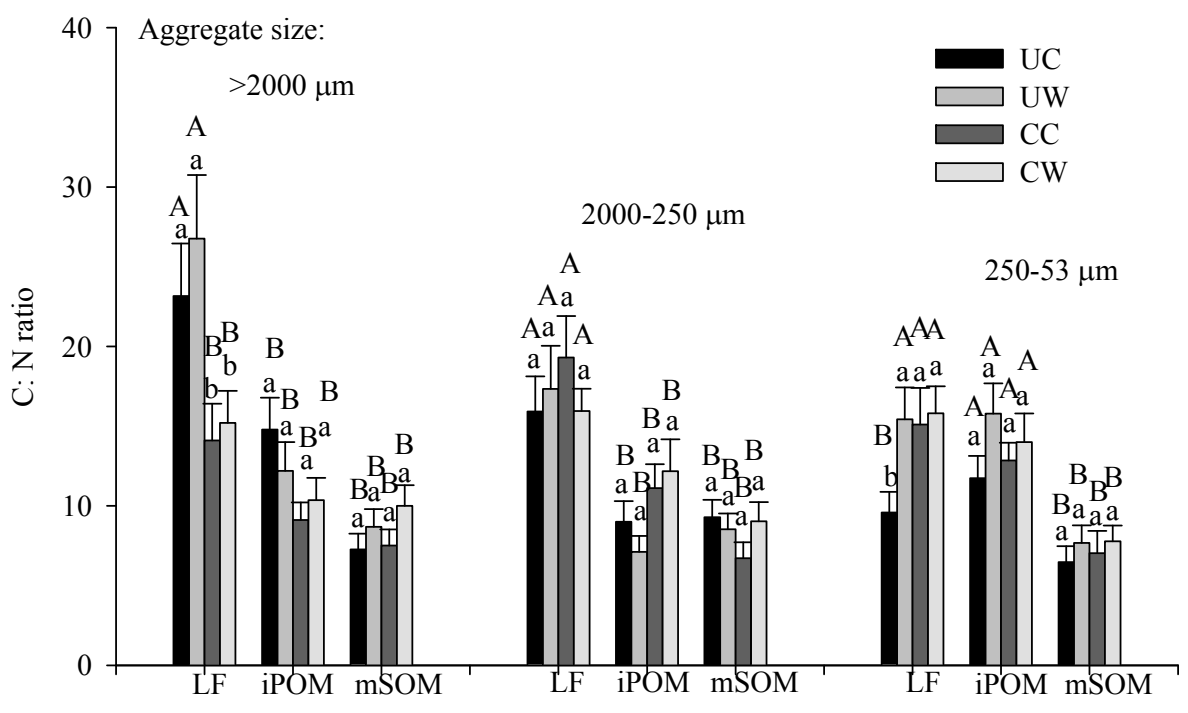

SOM classes

Fig. 4. C:N ratios of LF, iPOM, and mSOM of aggregate size classes under four treatments after nine years of warming and clipping. Values followed by a different lowercase letter are significantly different within SOM classes among treatments of each aggregate size. Values followed by a different capital are significantly different among SOM classes under treatments of each aggregate size. See Fig. 1 for abbreviations.

SOM fractions in warmed soils. Increased new $\mathrm{C}$ inputs from plant residue could result in faster decomposition of SOM (Dijkstra and Cheng, 2007). The decay rates for old $\mathrm{C}$ in whole soil were faster than all aggregates due to greater new $\mathrm{C}$ inputs (Table 6). This finding supports the evidence that soil aggregates physically protect certain SOM fractions, resulting in pools with longer turnover times (Six et al., 1998). Although LF generally represent only a small proportion of total soil C (Gregorich et al., 2006), changes in C stocks following changes in species composition can be more pronounced in LF compared to bulk soil (Schwendenmann and Pendall, 2006). Our results showed that warming-induced increase in $\mathrm{C}_{4}$-derived $\mathrm{C}$ in $\mathrm{LF}$ was larger than in $\mathrm{POM}$ and $\mathrm{mSOM}$ in all aggregate sizes (Fig. 5). Meanwhile, organic matter in LF fractions is readily accessible to microbes, as reflected by their initial rapid loss (Fontaine et al., 2004; Pendall et al., 2004). Warming caused no significant decreases in C content in LF in all SOM size fractions except in 2000$250 \mu \mathrm{m}$ aggregates in clipped plots (Table 4), possibly due to a rapid loss of labile substrates in LF (Table 6). With increasing degree of decomposition, organic matter may be transferred to more stabilized soil fractions. In contrast to rapid decomposition of $\mathrm{C}_{4}$-derived $\mathrm{C}$ from $\mathrm{LF}$, some $\mathrm{C}_{4}$-derived $\mathrm{C}$ remained in $\mathrm{POOM}$ fractions with slower turnover rates (Table 6). iPOM and $\mathrm{mSOM}$ accounted for the largest fraction of soil organic $\mathrm{C}$ and $\mathrm{N}$ contents in all sized aggregates (Table 4). Warming did not significantly effect soil organic C and $\mathrm{N}$ contents in $\mathrm{PPOM}$ and $\mathrm{mSOM}$ fractions, supporting the view that the heavy and mineral associated recalcitrant frac- tions that maintain physical and chemical stabilization (e.g., Six et al., 1998).

To conclude, we found that nine years of experimental warming caused no significant increases in soil organic $\mathrm{C}$ and $\mathrm{N}$ content in any soil fraction at our site. Warming did not significantly effect soil aggregate distribution and stability. However, warming did increase $\mathrm{C}_{4}$-derived $\mathrm{C}$ input into all fractions, particularly in LF of all aggregate size classes. Significant C loss in whole soil and labile components of LF under warming likely offset increased overall SOM inputs. Under warming, ${ }^{15} \mathrm{~N}$ values of soil fractions were more enriched than in the controls, indicating increased $\mathrm{N}$ transformation under warming. $\mathrm{C}: \mathrm{N}$ ratios and differences in natural abundance of $\delta^{13} \mathrm{C}$ and $\delta^{15} \mathrm{~N}$ in SOM fractions are associated with an increasing degree of decomposition across density fractions with increasing mineral association. The $\delta^{13} \mathrm{C}$ value of SOM is controlled by multiple factors, including hydrology, soil temperature, substrate, and vegetation, but turnover times based on natural abundance stable isotope methods tend to be more related to recent $\mathrm{C}$ inputs and $\mathrm{C}$ pools associated with the $\mathrm{C}_{3} / \mathrm{C}_{4}$ vegetation type conversion (Six and Jastrow, 2002). Lack of variability in the controls in this study might not provide rigorous statistical tests of warming effects on changes in $\delta^{13} \mathrm{C}$ of SOM. However, environment-induced changes in $\delta^{13} \mathrm{C}$ of SOM are small relative to changes caused by $\mathrm{C}_{3} / \mathrm{C}_{4}$ litter inputs, which do not strongly influence $\delta^{13} \mathrm{C}$ to trace $\mathrm{SOM}$ dynamics following changes in litter inputs (Wedin et al., 1995; Six and Jastrow, 2002). Our results suggest that shifts in species composition 


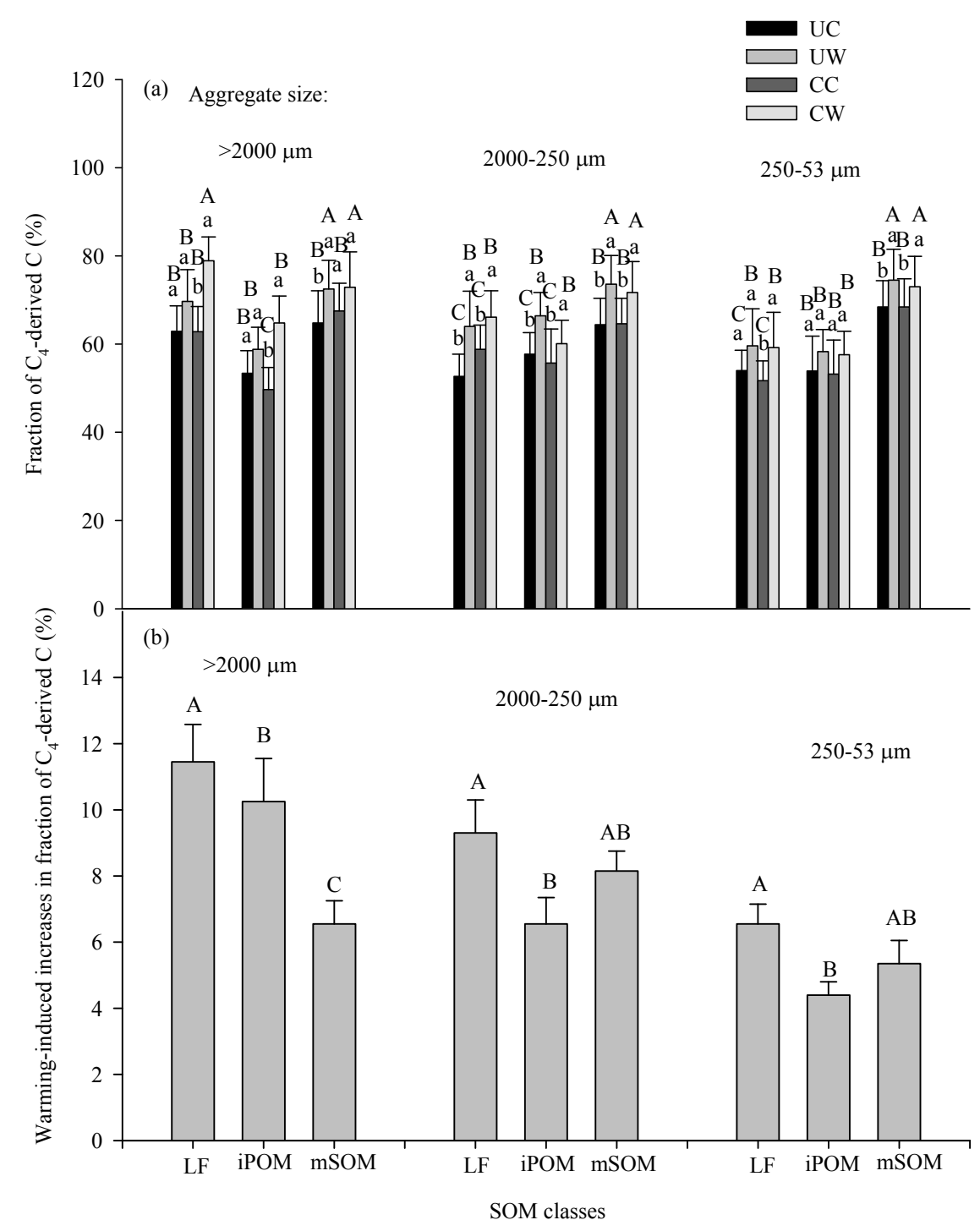

Fig. 5. Fraction of $\mathrm{C}_{4}$-derived $\mathrm{C}$ in the $\mathrm{LF}$, iPOM, and mSOM of aggregate size classes under four treatments after nine years of warming and clipping (a), and warming-induced increases in the fraction of $\mathrm{C}_{4}$-derived $\mathrm{C}$ in $\mathrm{LF}$, iPOM, and mSOM of SOM classes in the warmed soils (b). See Fig. 4 for the explanation of the symbols.

under warming could potentially modify SOM quality and decomposition and consequently effect ecosystem functions. Physical fractionation methods combined with isotope analyses in our study were an attempt to better understand SOM dynamics in response to global warming by acknowledging that SOM consists of a continuum of substrates with different turnover times. To accurately predict the effects of global warming on ecosystem processes, we need ecological models and long-term experiments to project future changes in ecosystem $\mathrm{C}$ and $\mathrm{N}$ cycles in response to multifactor global change.
Acknowledgements. This research was financially supported by National Science Foundation (NSF) under grants DEB 0078325 and DEB 0743778; by the Office of Science (BER), Department of Energy, grants no. DEFG02-006ER64319 and through the Midwestern Regional Center of the National Institute for Climatic Change Research at Michigan Technological University, under award number DE-FC02-06ER64158. We thank Meng Lu, Shenfei Fei, Xiaolei Yan for assistance in the field, Thomas L. Millican for assistance with laboratory analyses.

Edited by: J. Leifeld 


\section{References}

An, Y., Wan, S., Zhou, X., Subeda, A., Wallace, L. L., and Luo, Y.: Plant nitrogen concentration, use efficiency, and contents in a tallgrass prairie ecosystem under experimental warming, Glob. Change Biol., 11, 1733-1744, 2005.

Auerswald, K., Wittmer, M. H. O. M., Männel, T. T., Bai, Y. F., Schäufele, R., and Schnyder, H.: Large regional-scale variation in $\mathrm{C} 3 / \mathrm{C} 4$ distribution pattern of Inner Mongolia steppe is revealed by grazer wool carbon isotope composition, Biogeosciences, 6, 795-805, doi:10.5194/bg-6-795-2009, 2009.

Balesdent, J.: The significance of organic separates to carbon dynamics and its modelling in some cultivated soils, Eur. J. Soil Sci., 47, 485-493, 1996.

Batjes, N. H. and Sombroek, W. G.: Possibilities for carbon sequestration in tropical and subtropical soils, Glob. Change Biol., 3, 161-173, 1997.

Bijoor, N. S., Czimczik, C. I., Pataki, D., and Billings, S. A.: Effects of temperature and fertilization on nitrogen cycling and community composition of an urban lawn, Glob. Change Biol., 14, 2119-2131, 2008.

Cheng, X., Luo, Y., Chen, J., Lin, G., Chen, J., and Li, B.: Shortterm $\mathrm{C}_{4}$ plant Spartina alterniflora invasions change the soil carbon in $\mathrm{C}_{3}$ plant-dominated tidal wetlands on a growing estuarine Island, Soil Biol. Biochem., 38, 3380-3386, 2006.

Cheng, X., Luo, Y., Su, B., Zhou, X., Niu, S., Sherry, R. Weng, E., and Zhang, Q.: Experimental warming and clipping altered litter carbon and nitrogen dynamics in a tallgrass prairie, Agr. Ecosyst. Environ., 138, 206-216, 2010.

Davidson, E. A. and Janssens, I. A.: Temperature sensitivity of soil carbon decomposition and feedbacks to climate change, Nature, 440, 165-173, 2006.

Day, T. A., Ruhland, C., and Xiong, F. S.: Warming increases aboveground plant biomass and $\mathrm{C}$ stocks in vascular-plantdominated Antarctic tundra, Glob. Change Biol., 14, 1827-1843, 2008.

Dawson, T. E., Mambelli, S., Plamboeck, A. H., Templer, P. H., and Tu, K. P.: Stable isotopes in plant ecology, Annu. Rev. Ecol. Syst., 33, 507-559, 2002.

Del Galdo, I., Six, J., Peressotti, A., and Cotrufo, M. F.: Assessing the impact of land-use change on soil sequestration in agriculture soils by means of organic matter fraction and stable C isotopes, Glob. Change Biol., 9, 1204-1213, 2003.

Desjardins, T., Barros, E., Sarrazin, M., Girardin, C., and Mariotti, A.: Effects of forest conversion to pasture on soil carbon content and dynamics in Brazilian Amazonia, Agr. Ecosyst. Environ., 103, 365-373, 2004.

Dijkstra, F. A. and Cheng, W.: Interactions between soil and tree roots accelerate long-term soil carbon decomposition, Ecol. Lett., 10, 1046-1053, 2007.

Elliott, E. T.: Aggregate structure and carbon, nitrogen, and phosphorus in native and cultivated soils, Soil Sci. Soc. Am. J., 50, 627-633, 1986.

Fissore, C., Giardian, C. P., Kolka, R., Trettin, C. C., King, G. M., Jurgensen, M. F. Barton, C. D., and Mcdowell, S. D.: Temperature and vegetation effects on soil organic carbon quality along a forest mean annual temperature gradient in North America, Glob. Change Biol., 14, 193-205, 2008.

Fontaine, S., Bardoux, G., Abbadie, L., and Mariotti, A.: Carbon input to soil may decrease soil carbon content, Ecol. Lett., 7,
314-320, 2004.

Gregorich, E. G., Beare, M. H., Mckim, U. F., and Skjemstad, J. O.: Chemical and biological characteristics of physically uncomplexed organic matter, Soil Sci. Soc. Am. J., 70, 975-985, 2006.

Jastrow, J. D.: Soil aggregate formation and the accrual of particulate and mineral-associated organic matter, Soil Biol. Biochem., 28, 665-676, 1996.

John, B., Yamashita, T., Ludwig, B., and Flessa, H.: Storage of organic carbon in aggregate and density fractions of silty soils under different types of land use, Geoderma, 128, 63-79, 2005.

Kimball, B. A.: Theory and performance of an infrared heater for ecosystem warming, Glob. Change Biol., 11, 2041-2056, 2005.

Kramer, M. G., Sollins, P., Sletten, R. S., and Swart, P. K.: N isotope fractionation and measures of organic matter alteration during decomposition, Ecology, 84, 2021-2025, 2003.

Lal, R.: Sequestration of atmospheric $\mathrm{CO}_{2}$ in global carbon pools, Energ. Environ. Sci., 1, 86-100, 2008.

Liao, J. D., Boutton, T. W., and Jastrow, J. D.: Organic matter turnover in soil physical fractions following woody plant invasion of grassland: Evidence from natural ${ }^{13} \mathrm{C}$ and ${ }^{15} \mathrm{~N}$, Soil Biol. Biochem., 38, 3197-3210, 2006.

López-Ulloa, M., Veldkamp, E., and de Koning, H. G. J.: Soil carbon stabilization in converted tropical pastures and forests depends on soil type, Soil Sci. Soc. Am. J., 69, 1110-1117, 2005.

Luo, Y., Wan, S., Hui, D., and Wallace, L. L.: Acclimatization of soil respiration to warming in tallgrass prairie, Nature, 413, 622 625, 2001.

Luo, Y., Sherry, B., Zhou, X., and Wan, S.: Terrestrial carboncycle feedback to climate warming: experimental evidence on plant regulation and impacts of biofuel feedstock harvest, Glob. Change Biol. Bioen., 1, 62-74, 2009.

IPCC.: Climate Change 2007: The Scientific Basis, Cambridge University Press, New York, USA, 2007.

Maia, S. M. F., Ogle, S. M., Cerri, C. E. P., and Cerri, C. C.: Soil organic carbon stock change due to land use activity along the agricultural frontier of the southwestern Amazon, Brazil, between 1970 and 2002, Glob. Change Biol., 16, 2775-2788, 2010.

Marin-Spiotta, E., Silver, W. L., Swanston, C. W., and Ostertag, R.: Soil organic matter dynamics during 80 years of reforestation of tropical pastures. Glob. Change Biol., 15, 1584-1597, 2009.

Niu, S., Sherry, R. A., Zhou, X., Wan, S., and Luo, Y.: Nitrogen regulation of the climate-carbon feedback: evidence from a longterm global change experiment, Ecology, 91, 3261-3273, 2010.

Pendall, E., Bridgham, S., Hanson, P. J., Hungate, B., Kicklighter, D. W., Johnson, D. W., Law, B. E., Luo, Y., Megonigal, J. P., Olsrud, M., Ryan, M. G., and Wan, S.: Below-ground process responses to elevated $\mathrm{CO}_{2}$ and temperature: a discussion of observations, measurement methods, and models, New Phytol., 162, 311-322, 2004.

Phillips, D. L. and Gregg, J. W.: Uncertainty in source partitioning using stable istopes, Oecologia, 127, 171-179, 2001.

Puget, P., Chenu, C., and Balesdent, J.: Total and young organic matter distributions in aggregate of silty cultivated soils, Eur. J. Soil Sci., 46, 499-459, 1995.

Robinson, D.: ${ }^{15} \mathrm{~N}$ as an integrator of the nitrogen cycle, Trends Ecol. Evol., 16, 153-162, 2001.

Rustad, L. E., Campbell, J. L., Marion, G. M., Norby, R. J., Mitchell, M. J., Hartley, A. E., Cornelissen, J. H. C., and Gurevitch, J.: A meta-analysis of the response of soil respiration, net 
nitrogen mineralization, and aboveground plant growth to experimental ecosystem warming, Oecologia, 126, 543-562, 2001.

Schwendenmann, L. and Pendall, E.: Effects of forest conversion into grassland on soil aggregate structure and carbon storage in Panama: evidence from soil carbon fractionation and stable isotopes, Plant Soil, 288, 217-232, 2006.

Scott, N. A.: Soil aggregation and organic matter mineralization in forests and grasslands: Plant species effects, Soil Sci. Soc. Am. J., 62, 1081-1089, 1998.

Shaw, M. R. and Harte, J.: Response of nitrogen cycling to simulated climate change: differential responses along a subalpine ecotone, Glob. Change Biol., 7, 193-210, 2001.

Six, J. and Jastrow, J. D.: Organic matter turnover, in: Encycloedia of soil science, edited by: Lal, R., Marcel Dekker, New York, NY, USA, 936-942, 2002.

Six, J., Elliott, E. T., Paustian, K., and Doran, J. W.: Aggregation and soil organic matter accumulation in cultivated and native grass soils, Soil Sci. Soc. Am. J., 62, 1367-1377, 1998.

Six, J., Paustian, K., Elliott, E. T., and Combrink, C.: Soil structure and organic matter: I. Distribution of aggregate-size classes and aggregate-associated carbon, Soil Sci. Soc. Am. J., 64, 681-689, 2000.

Trumbore, S. E.: Age of soil organic matter and soil respiration: radiocarbon constraints on belowground $\mathrm{C}$ dynamics, Ecol. Appl., 10, 399-411, 2000.

Van Groenigen, K. J., Harris, A., Horwath, W. R., Hartwig, U., and Van Kessel, C.: Linking sequestration of ${ }^{13} \mathrm{C}$ and ${ }^{15} \mathrm{~N}$ in aggregates in a pasture soil following 8 years of elevated atmospheric $\mathrm{CO}_{2}$, Glob. Change Biol., 8, 1094-1108, 2002.
Von Fischer, J. C., Tieszen, L. L., and Schimel, D. S.: Climate controls on $\mathrm{C}_{3}$ vs. $\mathrm{C}_{4}$ productivity in North American grassland from carbon isotope composition of soil organic matter, Glob. Change Biol., 14, 1141-1155, 2008.

Wan, S., Hui, D., Wallace, L., and Luo, Y.: Direct and indirect effects of experimental warming on ecosystem carbon processes in a tallgrass prairie, Global Biogeochem. Cy., 19, GB2014, doi:10.1029/2004GB002315, 2005.

Wedin, D., Tieszen, L. L., Bewey, B., and Pastor, J.: Carbon isotope dynamics during grass decompostion and soil organic matter formation, Ecology, 76, 1383-1392, 1995.

Welker, J. M., Fahnestock, J. T., Henry, G. H. R., O’Dea, K. W., and Chimner, R. A.: $\mathrm{CO}_{2}$ exchange in three Canadian High Arctic ecosystems: response to long-term experimental warming, Glob. Change Biol., 12, 1981-1995, 2004.

Wynn, J. and Bird, M.: $\mathrm{C}_{4}$-derived soil organic carbon decomposes faster than its $\mathrm{C}_{3}$ counterpart in mixed $\mathrm{C}_{3} / \mathrm{C}_{4}$ soils, Glob. Change Biol., 13, 2206-2217, 2007.

Zhou, X., Wan, S., and Luo, Y.: Source components and interannual variability of soil $\mathrm{CO}_{2}$ efflux under experimental warming and clipping in a grass ecosystem, Glob. Change Biol., 13, 761-775, 2007. 